\title{
Nervus Olfaktorius: Dasar, Klinis Medis, dan Psikologis
}

\author{
Pingkan Ruru, ${ }^{1}$ Taufiq Fredrik Pasiak, ${ }^{2}$ Martha Marie Kaseke ${ }^{2}$
}

\author{
1Program Studi Pendidikan Dokter Fakultas Kedokteran Universitas Sam Ratulangi \\ Manado, Indonesia. \\ ${ }^{2}$ Bagian Anatomi-Histologi Fakultas Kedokteran Universitas Sam Ratulangi Manado, \\ Indonesia \\ Email: rurupingkan5@gmail.com
}

\begin{abstract}
The olfactory nerve is the first cranial nerve. Olfactory disorders can have a negative impact on health and quality of life and affect human psychology. The aim of this study is to determine the basic anatomical, clinical medical and psychological picture of the olfactory nerve. This study was in the form of a literature review. Literature is taken from one database, namely PubMed. The keywords used were olfactory nerve anatomy and clinical and psychology. After being selected with inclusion and exclusion criteria, 11 literature will be reviewed. Research from 11 literature reviewed found the basic anatomy of the olfactory nerve. Clinical disorders such as anosmia, hyposmia, phantosmia can occur in several nonneurodegenerative and neurodegenerative events or diseases, namely head injury trauma, Alzheimer's, Parkinson's and COVID-19. Psychological issues related to emotional and psychiatric disorders are also related to smell. In conclusion, the first cranial nerve is the olfactory nerve or the olfactory nerve, which clinically can occur in neurogenerative and nonneurodegenerative diseases. Smell and its disturbances can have a psychological impact.
\end{abstract}

Keywords: olfactory nerve, anatomy, clinical, psychology.

\begin{abstract}
Abstrak: Nervus olfaktorius merupakan saraf kranial pertama. Gangguan olfaktorius dapat berdampak buruk pada kesehatan dan kualitas hidup serta memengaruhi psikologis manusia. Tujuan penelitian untuk mengetahui gambaran dasar anatomi, klinis medis dan psikologis dari nervus olfaktorius. Penelitian ini dalam bentuk literature review. Literatur diambil dari satu database yaitu PubMed. Kata kunci yang digunakan yaitu anatomi nervus olfaktorius dan klinis dan psikologis. Setelah diseleksi dengan kriteria inklusi dan eksklusi didapatkan 11 literatur yang akan direview. Hasil penelitian dari 11 literatur yang direview didapatkan anatomi dasar nervus olfaktorius. Gangguan klinis seperti anosmia, hiposmia, phantosmia dapat terjadi pada beberapa kejadian atau penyakit non-neurodegeneratif dan neurodegeneratif yaitu Trauma cedera kepala, Alzheimer, Parkinson dan COVID-19. Psikologis yang berkaitan dengan emosional dan gangguan psikiatri juga berhubungan dengan penciuman. Sebagai simpulan, saraf kranial pertama adalah nervus olfaktorius atau disebut saraf penciuman, secara klinis bisa terjadi pada penyakit neurogeneratif dan non-neurodegeneratif. Penciuman dan gangguannya dapat memengaruhi psikologis.
\end{abstract}

Kata kunci: Saraf olfaktori, anatomi, klinis, psikologi.

\section{PENDAHULUAN}

Nervus olfaktorius adalah saraf sensorik murni (sensorik khusus) berperan untuk menyampaikan impuls saraf yang dapat diinterpretasikan oleh otak sebagai rangsangan atau sensasi suatu bau. Nervus olfaktorius merupakan saraf kranial pertama. Dari sudut pandang anatomis, saraf ini berjalan di dekat saraf terminal dan saraf vomeronasal, meskipun ketiga saraf tersebut dapat dengan mudah dibedakan. Nervus olfaktorius dimulai dari lamina propria dari epitel olfaktorius yang terletak di dalam rongga hidung. ${ }^{1}$ 
Akson dari neuron sensorik penciuman bertemu dan membentuk beberapa fasikula: fila olfaktoria, setelah meninggalkan rongga hidung fila olfaktoria melintasi lamina cribrosa dari tulang ethmoid dan masuk ke otak. Di dalam otak, nervus olfaktorius berakhir di bohlam penciuman yang neuronnya menerima kontak sinaptik dari terminal akson penciuman. ${ }^{2}$ Fungsi utama penciuman yaitu mengenali dan mengidentifikasi bau yang berbeda. ${ }^{3}$

Disfungsi penciuman memengaruhi sekitar $20 \%$ dari populasi orang dewasa umum $^{4}$ Satu hingga dua persen orang Amerika Utara melaporkan masalah dengan indra penciumannya. Masalah dengan indra penciuman meningkat seiring bertambahnya usia. Dalam sebuah penelitian, hampir seperempat pria usia 60 hingga 69 tahun mengalami gangguan penciuman. $^{5}$

Penciuman dapat memberikan informasi untuk mendeteksi adanya peringatan bau bahaya dari lingkungan serta berperan dalam pengalaman yang menyenangkan dalam hidup baik saat makan maupun jalan-jalan, karena itu, gangguan penciuman atau kehilangan indra penciuman juga dapat berdampak buruk pada kesehatan dan kualitas hidup seseorang. ${ }^{6}$

Penciuman terkait erat dengan pemrosesan emosi dan suasana hati. ${ }^{7}$ Gangguan suasana hati dapat memengaruhi penciuman persepsi dengan cara berbeda.

Hubungan yang erat antara penciuman dan emosi membuat bau menjadi alat yang sangat berguna untuk neuropsikologi modalitas sensorik utama yang digunakan untuk berkomunikasi dengan lingkungan. Oleh karena itu, manusia yang memiliki gangguan atau kehilangan indera penciumannya seringkali mengalami depresi. ${ }^{8}$

Berdasarkan penjelasan di atas, oleh karena itu peneliti tertarik untuk melakukan penelitian literature review untuk membahas dan menelaah berbagai informasi dan penjelasan ilmiah mengenai nervus olfaktorius berdasarkan dasar, klinis medis dan psikologis.

\section{METODE PENELITIAN}

Metode Penelitian ini berbentuk literature review. Pencarian data pada penelitian ini menggunakan satu database yaitu PubMed. Kata kunci yang digunakan yaitu olfactory nerve anatomy and clinical and psychology, peneliti mendapatkan artikel sebanyak $(n=671)$ menggunakan PubMed, yang sesuai dengan kata kunci tersebut. Hasil pencarian yang sudah didapatkan kemudian dilakukan skrining berdasarkan judul yang sesuai dengan tema literature review didapatkan 38 artikel $(\mathrm{n}=$ 38). Selanjutnya artikel diskrining abstrak dan fulltext berdasarkan kriteria inklusi dan ekslusi didapatkan 11 artikel $(\mathrm{n}=11)$.

\section{HASIL PENELITIAN}

Sebelas artikel memenuhi kriteria inklusi dan eksklusi dalam studi literatur ini. Sebelas artikel tersebut membahas mengenai gambaran dasar anatomi, klinis medis dan psikologis dari nervus olfaktorius. Tabel 1 memperlihatkan hasil seleksi literatur yang dipakai dalam penelitian ini.

\section{BAHASAN}

Berdasarkan hasil penelitian dari literatur-literatur yang direview, menggambarkan nervus olfaktorius berdasarkan anatominya dan beberapa gangguan klinis seperti pada penyakit neurodegenerative, non-neurodegeneratif, dan psikologis yang terkait dengan emosional manusia. Gambaran anatomi dari nervus olfaktorius yang pertama yaitu saraf penciuman tidak membentuk ikatan yang unik. Akson penciuman bergabung dengan akson lain dan membentuk beberapa bundel atau fasikula kecil atau disebut the fila olfactoria. Fasikula ini meninggalkan rongga hidung, melewati lamina cribrosa dari tulang ethmoid dan masuk ke otak. Keseluruhan fasikula ini disebut saraf penciuman. Kedua, neuron sensorik penciuman yang aksonnya mengintegrasikan saraf olfaktorius, menghubungkan rongga hidung dan otak tanpa relai apa pun. Ketiga, saraf penciuman terdiri dari akson tak bermielin. Keempat, saraf penciuman 
tidak mengandung sel schwann maupun oligodendrosit yang membungkus aksonnya, tapi itu mengandung glia penciuman ensheathing, yang merupakan jenis glia yang unik untuk saraf ini. Kelima, akson penciuman berpartisipasi dalam sirkuit struktur bola tertentu dari neuropil yang unik di otak yaitu glomeruli olfaktorius. Keenam, akson saraf penciuman terus menerus diganti dan koneksi mereka di sistem saraf pusat terbentuk terus menerus. Akhirnya ketujuh, saraf penciuman bisa menjadi pintu gerbang masuk langsung virus, neurotoksin dan xenobiotik lainnya ke otak. Dengan cara yang sama, ini dapat digunakan sebagai portal masuk ke otak untuk zat-zat terapeutik, melewati sawar darah-otak. $^{2}$

Disfungsi penciuman sering terjadi, terutama di antara orang yang lebih tua. Antara 32\% dan $62 \%$ populasi lansia diperkirakan mengalami gangguan indera penciuman. Gambaran suatu studi pengalaman phantosmia yaitu persepsi bau dengan sumber bau tidak ada, pada sampel orang dewasa yang lebih tua berdasarkan populasi. Prevalensi phantosmia secara keseluruhan adalah 4,9\% dan hasil ini juga menunjukkan bahwa prevalensi phantosmia pada populasi umum lansia tidak dapat diabaikan. ${ }^{9}$

Tabel 1. Hasil Seleksi Literatur

\begin{tabular}{|c|c|c|c|c|c|c|}
\hline No & $\begin{array}{l}\text { Penulis } \\
\text { Jurnal } \\
\text { (Tahun) }\end{array}$ & $\begin{array}{l}\text { Lokasi } \\
\text { Penelit } \\
\text { ian }\end{array}$ & $\begin{array}{c}\text { Tujuan } \\
\text { Penelitian }\end{array}$ & $\begin{array}{c}\text { Metode } \\
\text { Penelitian }\end{array}$ & $\begin{array}{l}\text { Populasi } \\
\text { Penelitian }\end{array}$ & Hasil Penelitian \\
\hline 1. & $\begin{array}{l}\text { Crespo } \\
\text { et al } \\
(2018)^{2}\end{array}$ & Spain & $\begin{array}{l}\text { Untuk meng- } \\
\text { analisis bebe- } \\
\text { rapa ciri } \\
\text { anatomi dan } \\
\text { fisiologi dari } \\
\text { pasangan saraf } \\
\text { kranial pertama }\end{array}$ & $\begin{array}{l}\text { Anatomical } \\
\text { Record }\end{array}$ & - & $\begin{array}{l}\text { Saraf penciuman } \\
\text { adalah saraf sensorik } \\
\text { yang membawa } \\
\text { informasi penciuman } \\
\text { dari rongga hidung ke } \\
\text { otak dan merupakan } \\
\text { saraf kranial pertama. }\end{array}$ \\
\hline 2. & $\begin{array}{l}\text { Sara } \\
\text { Sjölund } \\
\text { et al } \\
(2017)^{9}\end{array}$ & $\begin{array}{l}\text { Stockh } \\
\text { olm } \\
\text { Sweden }\end{array}$ & $\begin{array}{l}\text { Untuk } \\
\text { menyelidiki } \\
\text { prevalensi } \\
\text { phantosmia pada } \\
\text { populasi umum } \\
\text { yang lebih tua, } \\
\text { dan bagaimana } \\
\text { hubungannya } \\
\text { dengan } \\
\text { penciuman dan } \\
\text { kognitif }\end{array}$ & $\begin{array}{l}\text { Population- } \\
\text { based } \\
\text { sample }\end{array}$ & 3363 orang & $\begin{array}{l}\text { Prevalensi keseluruhan } \\
\text { phantosmia adalah } \\
4,9 \% \text {, pada populasi } \\
\text { lanjut usia tidak dapat } \\
\text { diabaikan. }\end{array}$ \\
\hline 3. & $\begin{array}{l}\text { Alex } \\
\text { Carignan } \\
\text { et al } \\
(2020)^{10}\end{array}$ & $\begin{array}{l}\text { Quebec, } \\
\text { Kanada }\end{array}$ & $\begin{array}{l}\text { Untuk } \\
\text { memastikan } \\
\text { apakah anosmia } \\
\text { dan dysgeusia } \\
\text { merupakan gejala } \\
\text { spesifik di antara } \\
\text { mereka yang } \\
\text { dites positif } \\
\text { mengidap } \\
\text { sindrom } \\
\text { pernapasan akut } \\
\text { parah (SARS- } \\
\text { CoV-2) }\end{array}$ & $\begin{array}{l}\text { Case- } \\
\text { control } \\
\text { study }\end{array}$ & $\begin{array}{l}\text { Semua orang } \\
\text { dewasa (usia } \geq \\
18 \text { tahun) yang } \\
\text { menjalani } \\
\text { pengujian } \\
\text { SARS-CoV-2 }\end{array}$ & $\begin{array}{l}\text { Hubungan yang kuat } \\
\text { antara gejala } \\
\text { penciuman, gustatory, } \\
\text { dan positif SARS- } \\
\text { CoV-2. }\end{array}$ \\
\hline
\end{tabular}


4. Rajiv

Singh

et al $(2018)^{11}$
Sheffield Untuk menilai

kejadian anosmia

dalam kelompok

Traumatic Brain

Injury (TBI)

campuran yang

besar dan

memeriksa

hubungan dengan

cedera lain

5. Michaela

Dede

ciusova

et al

$(2020)^{12}$
Cohort 774 pasien

Insiden anosmia $19 \%$.

Pasca TBI insiden

meningkat dengan

keparahan TBI serta

ada kecurigaan pada

klinis depresi.
Prague, Untuk

Czech

Republic

mengungkap

hasil olfaktorius

dari reseksi

yang dilakukan
Prospec
tive
analysis

13 pasien yang menjalani

reseksi bedah

Olfactory

Groove

Meningioma

(OGM) dari

Desember

2013 hingga

Desember

2017

Untuk menilai

ambang

penciuman,

diskriminasi, dan

identifikasi serta

menilai korelasi

Olfactory

Dysfunction

dengan

neuropsikologis

pada Alzheimer

7. Ane

Miren

Crespo

et al

$(2018)^{14}$
Barce

lona,

Spain

Untuk meng-

karakterisasi pola

hiposmia pada

kelompok pasien

PD dan dengan

pasien hiposmik

penyakit non-

neurodegeneratif

lainnya seperti

cedera otak

traumatis (TBI).
Observa 60 pasien

tional Alzheimer

Cross-

sectional

study

36 pasien $\mathrm{PD}$,

20 pasien

hiposmia

sekunder

akibat ISPA,

19 pasien

dengan

hiposmia

sekunder

akibat TBI
Delapan pasien dengan normosmia pra operasi, lima tetap normosmik $(62,5 \%)$, satu memburuk menjadi hiposmia (12,5\%), dan dua memburuk menjadi anosmia (25\%). Untuk dua pasien dengan hiposmia pra operasi, satu tetap hiposmik dan satu memburuk menjadi anosmia. Untuk tiga pasien anosmik, dua tetap anosmik, dan satu membaik menjadi hiposmia.

Gangguan dalam diskriminasi dan identiifikasi penciuman tampak berkolerasi dengan tingkat kognitif. Olfactory Disease pada Alzheimer dapat menjadi indikator penurunan kognitif patologi dan struktural

Pasien PD mendapat skor lebih rendah dari kontrol pada deteksi bau dan Pasien TBI menunjukkan skor yang secara signifikan lebih rendah daripada kelompok studi lain di semua item penciuman. 
72 eBiomedik, Volume 9, Nomor 1, Januari-Juni 2021, hlm. 68-76

\begin{tabular}{|c|c|c|c|c|c|c|}
\hline 8. & $\begin{array}{l}\text { Cinzia } \\
\text { Cecchetto } \\
\text { et al } \\
(2017)^{15}\end{array}$ & $\begin{array}{l}\text { Roma, } \\
\text { Italy }\end{array}$ & $\begin{array}{l}\text { Untuk } \\
\text { menyelidiki } \\
\text { bagaimana } \\
\text { individu } \\
\text { alexithymic } \\
\text { memproses emosi } \\
\text { yang disampaikan } \\
\text { oleh bau }\end{array}$ & $\begin{array}{l}\text { Case- } \\
\text { control } \\
\text { study }\end{array}$ & $\begin{array}{l}62 \text { peserta sehat } \\
\text { dengan tingkat } \\
\text { alexithymia } \\
\text { tinggi (HA), } \\
\text { sedang (MA) } \\
\text { dan rendah } \\
\text { (LA). }\end{array}$ & $\begin{array}{l}\text { Kelompok HA dan } \\
\text { MA menunjukkan } \\
\text { respons fisiologis yang } \\
\text { berubah terhadap bau. }\end{array}$ \\
\hline 9. & $\begin{array}{l}\text { Anne } \\
\text { Kathrin } \\
\text { Bestgen } \\
\text { et al, } \\
2015^{16}\end{array}$ & $\begin{array}{l}\text { Bochum } \\
\text { Jerman }\end{array}$ & $\begin{array}{l}\text { Untuk menguji } \\
\text { hubungan antara } \\
\text { kualitas } \\
\text { emosional suatu } \\
\text { bau dan } \\
\text { kemungkinan } \\
\text { identifikasi }\end{array}$ & $\begin{array}{l}\text { Case- } \\
\text { contol } \\
\text { study }\end{array}$ & $\begin{array}{l}40 \text { peserta }(25 \\
\text { perempuan, } 15 \\
\text { laki-laki) }\end{array}$ & $\begin{array}{l}\text { Hubungan erat antara } \\
\text { bau, kualitas } \\
\text { emosionalnya serta } \\
\text { kemungkinan untuk } \\
\text { mengidentifikasi dan } \\
\text { memberi nama bau } \\
\text { dengan benar }\end{array}$ \\
\hline 10 & $\begin{array}{l}\text { David C. } \\
\text { Houghton } \\
\text { et al } \\
(2020)^{17}\end{array}$ & $\begin{array}{l}\text { Charles } \\
\text { ton, } \\
\text { South } \\
\text { Carolina, } \\
\text { USA }\end{array}$ & $\begin{array}{l}\text { Untuk } \\
\text { mengetahui } \\
\text { gangguan } \\
\text { sensitivitas bau } \\
\text { apakah penanda } \\
\text { perilaku tekanan } \\
\text { psikologis }\end{array}$ & Kuisioner & $\begin{array}{l}\text { Orang dewasa } \\
\text { dengan } \\
\text { sensitivitas bau } \\
\text { yang dilaporkan } \\
\text { sendiri yang } \\
\text { digambarkan } \\
\text { sebagai } \\
\text { gangguan } \\
\text { fungsional (OSI; } \\
\mathrm{n}=32 \text { ) dan } \\
\text { sensitivitas bau } \\
\text { yang tidak } \\
\text { mengganggu } \\
\text { (OS; } \mathrm{n}=17 \text { ) } \\
\text { fungsional (OSI; } \\
\mathrm{n}=32 \text { ) dan } \\
\text { sensitivitas bau } \\
\text { yang tidak } \\
\text { mengganggu } \\
(\mathrm{OS} ; \mathrm{n}=17 \text { ) }\end{array}$ & $\begin{array}{l}\text { Peningkatan sensitivitas } \\
\text { kecemasan, depresi, dan } \\
\text { stres hidup, ditemukan } \\
\text { untuk OSI. Sementara } \\
\text { OSI, hanya } \\
\text { menunjukkan } \\
\text { peningkatan tren dalam } \\
\text { deteksi bau obyektif dari } \\
\text { bau seperti asap, tetapi } \\
\text { tidak seperti mawar, } \\
\text { analisis lebih lanjut } \\
\text { mengungkapkan bahwa } \\
\text { peningkatan deteksi bau } \\
\text { seperti asap itu } \\
\text { berkorelasi positif } \\
\text { dengan sensitivitas } \\
\text { kecemasan. Sementara } \\
\text { OSI, hanya menunjuk- } \\
\text { kan peningkatan tren } \\
\text { dalam deteksi bau } \\
\text { obyektif dari bau seperti } \\
\text { asap. }\end{array}$ \\
\hline 11 & $\begin{array}{l}\text { Vidyulata } \\
\text { Kamath } \\
\text { et al } \\
(2017)^{18}\end{array}$ & $\begin{array}{l}\text { Amerika } \\
\text { Serikat }\end{array}$ & $\begin{array}{l}\text { Untuk memeriksa } \\
\text { identifikasi bau, } \\
\text { diskriminasi bau, } \\
\text { ambang deteksi, } \\
\text { dan kinerja } \\
\text { pemrosesan } \\
\text { hedonis bau pada } \\
\text { individu dengan } \\
\text { gangguan bipolar } \\
\text { I, gangguan } \\
\text { bipolar II, } \\
\text { kecemasan, dan } \\
\text { gangguan mental }\end{array}$ & $\begin{array}{l}\text { Commu } \\
\text { nity- } \\
\text { based } \\
\text { family } \\
\text { study }\end{array}$ & $\begin{array}{l}\text { Peserta di } \\
\text { National } \\
\text { Institute of } \\
\text { Mental Health } \\
\text { Family Study } \\
\text { of Affective } \\
\text { Spectrum } \\
\text { Disorder }\end{array}$ & $\begin{array}{l}\text { Menunjukkan bahwa } \\
\text { kesulitan identifikasi } \\
\text { bau mungkin ada pada } \\
\text { gangguan mood, } \\
\text { terutama bila ada fitur } \\
\text { psikotik. }\end{array}$ \\
\hline
\end{tabular}


Semakin banyak literatur yang menyebutkan anosmia dan dysgeusia sebagai gejala potensial infeksi SARS-CoV-2. Identifikasi 146 orang yang positif SARSCoV-2 di tahun 2020, menemukan bahwa anosmia dan dysgeusia adalah gejala paling khas yang terkait dengan infeksi SARSCoV-2 dan gejala ini bisa parah, seperti yang ditunjukkan oleh hilangnya persepsi bau seperti kopi dan sampah serupa dengan penelitian terhadap 417 pasien dengan COVID-19 ringan hingga sedang di mana disfungsi penciuman dan gangguan pencernaan dilaporkan masing-masing pada $85,6 \%$ dan $88,0 \%$ pasien. Dalam studi kasus-kontrol yang disesuaikan dengan usia ditemukan hubungan yang kuat antara gejala penciuman dan gustatory dengan positif SARS-CoV-2. Perbedaan anosmia yang terkait dengan SARS-CoV-2 dari anosmia nonspesifik yang terkait dengan virus pernapasan lain atau dengan hidung tersumbat. Anosmia yang dijelaskan oleh pasien SARS-CoV-2-positif tidak tergantung pada hidung tersumbat. Pasien yang mengalami bersin memiliki kemungkinan lebih rendah untuk terinfeksi. Gejala-gejala ini memengaruhi kemampuan untuk mengenali bau yang sering ditemukan dalam kehidupan sehari-hari dan tidak tergantung pada hidung tersumbat dan tetesan hidung, yang lebih sering diamati pada populasi kontrol. Hasil ini memperkuat saran bahwa anosmia dan dysgeusia harus dianggap sebagai ciri umum dan khas dari infeksi SARS-CoV-2. ${ }^{10}$

Gangguan klinis pada nervus olfaktorius menyebabkan disfungsi penciuman yang dapat diklasifikasikan sebagai kuantitatif (hiposmia dan anosmia) dan disfungsi kualitatif (parosmia dan phantosmia). Gambaran klinis medis mengenai disfungsi penciuman ini juga terkait pada beberapa penyakit atau kejadian seperti pada Traumatic Brain Injury (TBI) yang dapat mengakibatkan kerusakan pada jalur perifer atau sentral sistem penciuman. Bola olfaktorius dan saraf penciuman berisiko mengalami kerusakan akibat gaya geser yang disebabkan oleh cedera akselerasideselerasi. Oleh karena itu, komp likasi umum TBI lainnya adalah Gangguan Penciuman (Olfactory Disturbance / OD). Dilakukan penilaian fungsi penciuman dengan kepekaan terhadap butiran kopi yang diletakkan di bawah hidung. Hasil Insidensi keseluruhan anosmia adalah $19,7 \%$, dan insiden meningkat dengan keparahan TBI dan penyakit medis lainnya. Pasien TBI mendapatkan skor yang secara signifikan lebih rendah daripada kelompok studi lain di semua item penciuman. ${ }^{11}$

Penilaian fungsi penciuman tidak hanya penting dalam pengambilan keputusan pra operasi (pendekatan bedah, radikalitas reseksi) tetapi juga penting dalam mengevaluasi hasil bedah dalam operasi OGM. Normosmia pra operasi tampaknya menjadi faktor prognostik terpenting untuk hasil penciuman fungsional. Pada pasien normosmik, penciuman dipertahankan di $62,5 \%$ kasus. Terdapat hubungan antara volume meningioma yang lebih tinggi dengan fungsi penciuman yang lebih buruk sebelum dan setelah operasi. Hasil fungsional dalam kasus ini adalah normosmia pasca operasi di $50 \%$ dan hiposmia di $30 \%$. Lima proporsi pasien yang tidak bisa. ${ }^{12}$

Pada gangguan klinis selanjutnya terkait penyakit neurodegeneratif seperti penyakit Alzheimer yang dalam beberapa tahun terakhir, Olfactory Dysfunction (OD) adalah salah satu gejala klinis paling awal dan telah dianggap sebagai potensi klinis penanda untuk keparahan dan perkembangan Alzheimer Disease (AD). Pada perbandingan fungsi penciuman antara kelompok 275 Alzheimer DiseaseOlfactory Dysfunction (AD-OD) dan kelompok Alzheimer Disease-Non Olfactory Dysfunction (AD-NOD). Skor TDI, THR, DIS, dan ID secara signifikan lebih rendah pada kelompok AD-OD dibandingkan dengan kelompok AD-NOD, menunjukkan bahwa pasien dalam kelompok $\mathrm{AD}-\mathrm{OD}$ memiliki gangguan fungsi penciuman di ketiga aspek (ambang penciuman, diskriminasi, dan identifikasi). Diketahui bahwa baik memori deklaratif dan kemampuan penamaan bahasa berhubungan dengan hipokampus, sedangkan 
gyrus parahippocampal memainkan peran integral dalam kemampuan visuospasial. Oleh karena itu, domain kognitif ini terkait dengan hipokampus dan struktur di lobus temporal medial, yang merupakan bagian dari jalur olfaktorius. Diperkirakan 24,5\% orang lanjut usia memiliki gangguan fungsi penciuman yang tampaknya lebih umum pada pasien dengan AD. Selain Alzheimer, penyakit yang terkait juga yaitu Parkinson Disease (PD) Gangguan penciuman pada PD telah dipelajari secara ekstensif dalam beberapa tahun terakhir. Hampir $90 \%$ dari pasien PD menunjukkan defisit penciuman selama perjalanan penyakit. Hiposmia dapat muncul bahkan sebelum timbulnya gejala motorik, dengan adanya suatu penelitian yang menyatakan tentang pola hiposmia pada penyakit Parkinson, hampir 90\% dari pasien PD menunjukkan defisit penciuman selama perjalanan penyakit. Hiposmia dapat muncul bahkan sebelum timbulnya gejala motorik, yang sebenarnya merupakan gejala pra motorik yang sudah dikenal baik, hasil menunjukkan untuk bau saraf kranial pertama, pasien PD mendapat skor lebih rendah dari kontrol pada deteksi bau. $^{13}$

Individu alexithymic memproses emosi yang disampaikan oleh bau. Sampel dari 62 peserta sehat dengan tingkat alexithymia tinggi (HA), sedang (MA) dan rendah (LA). Kehadiran alexithymia mengakibatkan respon fisiologis yang berubah terhadap bau, meskipun tidak ada perbedaan dibandingkan dengan non-alexithymics yang diamati pada peringkat bau umum. Penelitian ini menunjukkan bahwa pada subjek yang sehat, alexithymia dikaitkan dengan reaksi emosional otonom yang berubah terhadap rangsangan penciuman. ${ }^{14}$

Penciuman juga memengaruhi aspek psikologis manusia terbukti erat kaitannya emosi dan penciuman, didukung oleh hubungan anatomis yang erat antara daerah pemrosesan emosi dan sistem penciuman. Sistem penciuman memproyeksikan langsung ke amigdala wilayah otak inti untuk pemrosesan emosi dan memori emosional. Suatu penelitian mengidentifikasi valensi dan dominasi kuadrat sebagai prediktor penting selanjutnya dari identifikasi bau. Bau yang dinilai netral lebih sulit diidentifikasi. Semakin tinggi nilai kuadrat valensi, yaitu semakin tinggi emosionalitas suatu bau tidak bergantung pada arah valensi, dan semakin dominan bau yang dirasakan, semakin tinggi kemungkinan untuk mengidentifikasi bau dengan benar. Bau dengan nilai valensi dan dominasi (kuadrat) yang lebih tinggi kemungkinan besar memiliki lebih banyak asosiasi emosional, berdasarkan pengalaman pribadi dan pembelajaran. Mengacu pada hubungan antara peristiwa emosional dan bau. Bau yang terkait dengan emosi kecemasan akibat pengalaman, misalnya bau rumah sakit, akan memengaruhi persepsi bau ini di masa mendatang. ${ }^{15}$

Temuan yang menawarkan wawasan gangguan sensitivitas bau, didefinisikan secara subyektif atau obyektif, dapat menjadi penanda jenis kecemasan dan tekanan psikologis tertentu. Hasil menunjukkan peningkatan sensitivitas kecemasan, kecemasan sifat, depresi, dan stres hidup, bahkan saat mengontrol kecemasan komorbiditas dan gangguan depresi, ditemukan untuk Gangguan Fungsional Penciuman (OSI) dibandingkan dengan Tidak Gangguan Fungsional Penciuman (OS). Sementara OSI dibandingkan dengan OS, hanya menunjukkan peningkatan tren dalam deteksi bau obyektif dari bau seperti asap, tetapi tidak seperti mawar, analisis lebih lanjut mengungkapkan bahwa peningkatan deteksi bau seperti asap itu berkorelasi positif dengan sensitivitas kecemasan. Penemuan ini menunjukkan bahwa orang dengan berbagai bentuk tekanan psikologis mungkin menemukan diri mereka secara signifikan terganggu oleh intoleransi terhadap bau, tetapi kepekaan bau yang dilaporkan sendiri tidak selalu berhubungan dengan kemampuan deteksi bau yang ditingkatkan. Peningkatan kepekaan terhadap bau seperti asap tampaknya terkait dengan kepekaan terhadap rangsangan ansiogenik yang tidak menyenangkan. Implikasi untuk patofisiologi ketakutan dan gangguan terkait kecemasan dibahas, juga 
menunjukkan bahwa individu dengan Major Depressive Disorder (MDD) menunjukkan akurasi identifikasi bau yang berkurang dibandingkan dengan kontrol yang sehat. Dalam kelompok gangguan bipolar, temuan ini tampaknya didorong oleh sebagian peserta yang memiliki ciri psikotik, dengan defisit yang sebanding dengan yang diamati pada skizofrenia. Valensi bau juga memengaruhi kemampuan identifikasi bau, karena mereka yang memiliki ciri psikotik menunjukkan identifikasi yang buruk terutama untuk bau yang menyenangkan. Pada individu dengan depresi berat, akurasi berkurang untuk bau netral. Secara kolektif, temuan ini menunjukkan bahwa kesulitan identifikasi bau mungkin ada pada gangguan mood, terutama bila ada fitur psikotik. Pada disfungsi penciuman global yang diamati pada skizofrenia mungkin bukan ciri dari kondisi neuropsikiatri lainnya. ${ }^{16,17,18}$

\section{SIMPULAN}

Saraf kranial pertama adalah nervus olfaktorius atau disebut saraf penciuman. Secara klinis, gangguan penciuman bisa terjadi pada penyakit neurogeneratif dan non-neurodegeneratif serta untuk penciuman dan gangguannya memengaruhi psikologis manusia.

\section{Konflik Kepentingan}

Penulis menyatakan tidak terdapat konflik kepentingan dalam studi ini.

\section{DAFTAR PUSTAKA}

1. Vilensky JA, Robertson WM, SuárezQuian CA. The Clinical Anatomy of the Cranial Nerves: The Nerves of "On Old Olympus Towering Top." Clin Anat Cranial Nerves Nerves "On Old Olympus Towering Top." Hoboken:WileyBlackwell, 2015.

2. Crespo C, Liberia T, Blasco-Ibáñez JM, Nácher J, Varea E. Cranial Pair I: The Olfactory Nerve. Anat Rec. 2019; Mar;302(3):405-27.
3. Devere R. Disorders of Taste and Smell. Contin Lifelong Learn Neurol. 2017; Apr;23(2):421-46.

4. Whitcroft KL, Hummel T. Clinical Diagnosis and Current Management Strategies for Olfactory Dysfunction: A Review. JAMA Otolaryngol - Head Neck Surg. 2019; 145(9):846-53

5. Anniko M, Bernal-Sprekelsen M, Bonkowsky V, Bradley P, Lurato S. Otorhinolaryngology, Head and Neck Surgery. Berlin: Springer, 2010.

6. Hoffman HJ, Rawal S, Li CM, Duffy VB. New chemosensory component in the U.S. National Health and Nutrition Examination Survey (NHANES): first-year results for measured olfactory dysfunction. Rev Endocr Metab Disord. 2016 Jun;17(2):221-40.

7. Pabel LD, Hummel T, Weidner K, Croy I. The impact of severity, course and duration of depression on olfactory function. J Affect Disord. 2018;238:194-203.

8. Bochicchio V, Winsler A. The psychology of olfaction: A theoretical framework with research and clinical implications. Psychol Rev. 2020;127(3):442-54.

9. Sjölund S, Larsson M, Olofsson JK, Seubert J, Laukka EJ. Phantom Smells : Prevalence and Correlates in a Population-Based Sample of Older Adults. 2017;42:309-18.

10. Carignan A, Valiquette L, Grenier C, Musonera JB, Nkengurutse D, Marcil-Héguy A, et al. Anosmia and dysgeusia associated with SARS-CoV-2 infection: an agematched case-control study. CMAJ. 2020;192(26):E702-7.

11. Singh R, Humphries T, Mason S, Lecky F, Dawson J, Sinha S. The incidence of anosmia after traumatic brain injury: the SHEFBIT cohort. Brain Inj. 2018;32(9):1122-8. 
12. Dedeciusova M, Svoboda N, Benes V, Astl J, Netuka D. Olfaction in Olfactory Groove Meningiomas. J Neurol Susg A Cent Eur Neurosurg 2020;81(4): 310-7.

13. Lian TH, Zhu WL, Li SW, Liu YO, Guo P, Zuo LJ, et al. Clinical, Structural, and Neuropathological Features of Olfactory Dysfunction in Patients with Alzheimer's Disease. J Alzheimer's Dis. 2019;70(2):413-23.

14. Cuevas AMC, Ispierto L, Vilas D, Planas A, Planas A, Isern I, et al. Distinctive Olfactory Pattern in Parkinson's Disease and NonNeurodegenerative Causes of Hyposmia. Neurodegener Dis. 2018;18(2-3):143-9.
15. Cecchetto C, Rumiati RI, Aiello M. Alexithymia and emotional reactions to odors. Sci Rep. 2017; 7(1):1-12.

16. Bestgen AK, Schulze P, Kuchinke L. Odor emotional quality predicts odor identification. Chem Senses. 2015;40(7):517-23.

17. Houghton DC, Howard SL, Uhde TW, Paquet C, Schlosser RJ, Cortese BM. Odor sensitivity impairment: A behavioral marker of psychological distress? CNS Spectr. 2019; 24(4):404-12.

18. Kamath V, Paksarian D, Cui L, Moberg PJ, Turetsky BI, Merikangas KR. Olfactory processing in bipolar disorder, major depression, and anxiety. Bipolar Disord. 2018; 20(6):547-55. 